\title{
Scar neuromas as triggers for headache after craniotomy: clinical evidence
}

\author{
Neuromas de cicatriz como gatilhos para cefaleia pós-craniotomia: evidência clínica \\ Karen dos Santos Ferreira, Fabiola Dach, José Geraldo Speciali
}

\begin{abstract}
We present four cases of headache with variable intensity, located in close proximity to a craniotomy incision which was performed for nontraumatic reasons. Since manual palpation of the scar often triggers pain, and infiltration with local anesthetics reduce or abolish the pain in some patients, we suggest that neuromas or nerve entrapment in the scars, as a result of the surgery, are responsible for headaches. Although local infiltrations or nerve blocks are often used for diagnostic reasons, herein we consider that they are also of therapeutic value. We review the current known pathophysiology of post-craniotomy headaches and present a hypothesis suggesting a greater recognition of the potential contribution of neuroma formation in areas of scars tissue to contribute to this kind of headache.
\end{abstract}

Key words: post-craniotomy headache, neuromas, nerve block.

\section{RESUMO}

Apresentamos quatro casos de cefaleia de variada intensidade, localizada junto à incisão de craniotomia, realizada por causas não traumáticas. Como a palpação manual da cicatriz desencadeava a dor e a infiltração local com anestésicos a reduzia ou abolia, apresentamos uma hipótese sugerindo a formação de neuromas de cicatriz na etiologia da dor. Sugerimos bloqueios anestésicos como ferramenta diagnóstica e terapêutica. Revisamos a fisiopatologia da cefaleia pós-craniotomia e apresentamos uma hipótese sugerindo a potencial contribuição da formação de neuromas de cicatriz na etiologia deste tipo de dor.

Palavras-Chave: cefaleia pós-craniotomia, neuromas, bloqueio nervoso.

Post-craniotomy headache $(\mathrm{PCH})$ is a secondary headache that appears as a consequence of neurosurgical interventions requiring craniotomy. It is defined by the current International Classification of Headache Disorders (ICHD-II) as a headache of variable intensity, most severe near the site of craniotomy motivated by non-traumatic reasons. Its onset happens within 7 days of the surgery ${ }^{1}$.

Headaches following craniotomies are reported in up to $91 \%$ of neurosurgical cases, and duration of pain after craniotomy seems to vary as a function of surgical location ${ }^{2-6}$. When the onset of PCH happens within days of the craniotomy, diagnosis is typically not difficult ${ }^{7,8}$. However, when the time elapsed between the craniotomy and headache onset is longer, diagnosis may be difficult and complex ${ }^{1}$.

Herein, we report 4 cases of headaches related to neurosurgical incisions that did not fulfill criteria for $\mathrm{PCH}$, with the purpose of gathering and sharing information about this poorly discussed headache type. This report was approved by the Ethics Committee of our Institution and signed consents were obtained.

\section{CLINICAL REPORTS}

\section{Case 1}

A 55-year-old woman, with a past history of migraine without aura, had neurosurgery to remove a benign tumor at the age of 38. Five years after the surgery (at the age of 43), she reported daily headaches which were located in the frontoparietal region and were typically severe (visual analog scale $=9$ (VAS)) and throbbing. Duration was up to 12 hours, and response to analgesics was poor. During the headaches, she had nausea and photophobia. She had used amitriptyline, propranolol, chlorpromazine, carbamazepine and topic capsaicine for the treatment of her pain, with little improvement. Because digital pressure of surgical scar would trigger headaches with 
the same characteristics, we decided to inject the most painful points of the scar with a solution of lidocaine $2 \%(1.5 \mathrm{~mL})$ and dexamethasone $10 \mathrm{mg} / 2 \mathrm{~mL}(0.5 \mathrm{~mL})$. We repeated the procedure three more times during the next four months. She reported important reduction in the frequency of her headaches, from daily to around once a month. She has been followed for 7 years, without worsening (Table).

\section{Case 2}

A 48-year-old woman with a past history of tension-type headache had surgery for aneurism clipping (left middle cerebral artery) at the age of 41 . Seven years after the surgery, she start experiencing severe episodes of pain $(\mathrm{VAS}=10)$ in the left temporal region. Pain was throbbing and of short duration, lasting 2 to 3 minutes. Attacks recurred several times each day. Pain was not associated with phonophobia, photophobia or autonomic signs. Previous treatments included the use of amitriptyline and diclofenac, without improvement. Digital pressure of specific points on the surgical scar triggered the exact same pain; therefore, we injected these points with a solution of lidocaine $2 \%(1.5 \mathrm{~mL})$ with dexamethasone $10 \mathrm{mg} / 2 \mathrm{~mL}(0.5 \mathrm{~mL})$. At follow-up (two months after injection), she reported having experienced only one mild attack. She has been followed for 2 years, without worsening (Figure).

\section{Case 3}

A 46-year-old woman had two craniotomies at the age of 30 , for surgical clipping of aneurisms in both middle cerebral arteries. She reported having no headaches until the surgery.

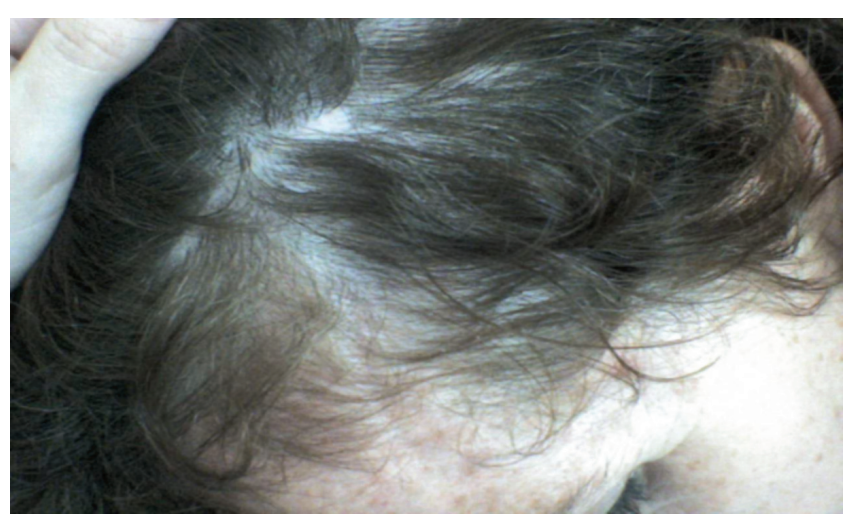

Figure. Scar triggers.
Nine years after the surgery, she reported headaches of gradual onset, felt on the right frontotemporal region, with throbbing (and sometimes burning) quality, and severe (VAS=10). Pain typically lasted 24 hours and was accompanied by ipsilateral conjuntival injection and lacrimation that persisted throughout the attack. Attacks were aggravated by routine physical activity, but they were not accompanied by agitation, nausea, photophobia or phonophobia. Frequency was from 3 to 4 times per week, with pain-free intervals lasting more than 24 hours. Because digital pressure of the surgical region triggered the pain, we injected the most painful points of the surgical scar with a solution of lidocaine $2 \%(1.5 \mathrm{~mL})$ plus dexamethasone $10 \mathrm{mg} / 2 \mathrm{~mL}(0.5 \mathrm{~mL})$. She reported total improvement of pain and no headache attacks at the followup (two years after the injections) (Table).

\section{Case 4}

A 45-year-old man had right temporal lobectomy for the treatment of epilepsy at the age of 43 . He had no past history of headaches. One month after the procedure, he reported onset of headache attacks (right temporal region). Headaches were throbbing, severe (VAS=8), with photophobia and tearing ipsilateral to the pain side. Attacks lasted up to 72 hours and happened once a week. Amitriptyline had been tried, without improvement. Because digital pressure of the surgical region triggered the headaches, we injected the most painful points of the surgical scar with a solution of lidocaine $2 \%$ (1.5 mL) and dexamethasone $10 \mathrm{mg} / 2 \mathrm{~mL}$ (0.5 mL). After two weeks, patient reported significant reductions on frequency (now twice a month), duration ( $<24$ yours) and severity (VAS=4) of the attacks. He has been followed for 2 years, without headaches (Table).

\section{DISCUSSION}

In the currently study, we reported four cases that did not fulfill criteria for PCH (headaches appeared after 1 week), but had headaches associated to neurosurgical scars. Case 1 describes a patient with migraine-like headache and substantial increase in the frequency of the headaches five years after the surgical procedure. Injection on painful sites induced remission. Case 2 describes a patient with episodic tensiontype headaches who, 7 years after the craniotomy, developed

Table. Cases of headaches related to neurosurgical incisions.

\begin{tabular}{|c|c|c|c|c|c|c|c|}
\hline $\begin{array}{l}\text { Subject } \\
\text { gender/ age }\end{array}$ & Surgery & $\begin{array}{l}\text { Previous } \\
\text { headache }\end{array}$ & Pain feature & $\begin{array}{l}\text { Visual analogic } \\
\text { scale }\end{array}$ & $\begin{array}{l}\text { Scar } \\
\text { triggers }\end{array}$ & $\begin{array}{l}\text { Oral medication } \\
\text { response }\end{array}$ & $\begin{array}{l}\text { Injection } \\
\text { response }\end{array}$ \\
\hline$F, 55$ & Benign tumor & Migraine & Throbbing & 9 & Yes & Partial & Important \\
\hline$F, 48$ & $\begin{array}{l}\text { Aneurism } \\
\text { clipping }\end{array}$ & Tension Type & Throbbing & 10 & Yes & Partial & Total \\
\hline $\mathrm{F}, 46$ & $\begin{array}{l}\text { Aneurism } \\
\text { clipping }\end{array}$ & No & $\begin{array}{l}\text { Throbbing/ } \\
\text { burning }\end{array}$ & 10 & Yes & Not used & Total \\
\hline$M, 48$ & Epilepsy & No & Throbbing & 8 & Yes & Without improvement & Important \\
\hline
\end{tabular}


a different headache syndrome, characterized by frequent, short duration attacks. Cases 3 and 4 describe patients without past history of headaches. After the craniotomy (after 1 month in one case and after 9 years in the other), they developed new onset headaches. Headaches had some migrainous characteristics and were associated with autonomics signs ipsilateral to the pain.

In these cases, the time elapsed between the surgical procedures and the development, worsening, or modification of the headaches varied from 30 days to 9 years. Headaches were throbbing, severe and worse in proximity to the surgical scars. Duration of attacks varied from a few minutes to 72 hours, and monthly frequency of attacks ranged from 12 to 30 days. Prophylactic use of amitriptyline, propranolol, chlorpromazine, carbamazepine and topic capsaicine resulted in little or no improvement. Despite the long time between surgery and the onset of headache, we consider the causal relation based on: 1. Difficulty in fulfilling the necessary criteria for primary headaches (cases 2, 3 and 4); 2. Limited response to standard preventive medications (cases 1 and 4); 3. Pain happened mainly and was stronger in the region of the craniotomy, being ipsilateral to the surgery (all cases); 4. Pain was invariably triggered by pressing specific points on the surgical scars (all cases); 5. Patients experienced total remission or significant improvement of the headaches after the injection of the previously identified trigger points (all cases).

The pathophysiology of $\mathrm{PCH}$ seems to involve meningeal inflammation ${ }^{9}$, nerve compression, nerve entrapment, muscular and meningeal fibrosis ${ }^{10}$, and central sensitization $^{11}$. The role of neuromas as a cause of $\mathrm{PCH}$ has been suggested $^{5}$. Neuromas are characterized by abnormal tissue growth (regenerating axons surrounded by connective tissue). They typically appear after traumatic injuries, as a consequence of pressure or laceration of the nerves. It is hypothesized that abnormal voltage-dependent $\mathrm{Na}$ channels in these neuromas may induce a state of axonal hyperexcitability. Because neuromas have aberrant conductive capacity, abnormal sensorial (and nociceptive) perception may arise $\mathrm{e}^{12,13}$. The continuous input generated by these axons would be conducted to the second and third neurons (trigeminal nucleus caudalis and thalamus). This sensitization, induced by neuromas, would contribute to the worsening or change in the pattern of a pre-existing headache, or to the development of a new headache ${ }^{14-17}$. Accordingly, the role of neuromas in both initiation and maintenance of pain has been recognized in other pain disorders such as complex regional pain syndrome $e^{18,19}$.

Based on lessons learned with these four cases, we emphasize three points. First, from a temporal perspective, despite the relation between neurosurgical scars and headaches, it is impossible to classify our cases as PCH as per the ICHD-II ${ }^{20}$.

A second consideration regards the pathophysiology of these headaches. Since manual palpation of the scar often triggers pain, and infiltration with local anesthetics reduce or abolish the pain in some patients, we suggest that neuromas or nerve entrapment in the scars as a result of the surgery are responsible for headaches.

Finally, although local infiltrations or nerve blocks are often used for diagnostic reasons, herein, we consider that they are also of therapeutic value ${ }^{21,22}$. Some patients have incomplete relief after the first infiltration, and may need further infiltrations. However, based on our casuistic, permanent improvement after a single infiltration may be possible.

We reported a series of four patients with headaches related to incisional neurosurgical scars. We hypothesized that the surgical trauma predisposes to the development of neuromas or nerve entrapments that may become triggers for headaches (development and worsening), perhaps due to a mechanism of central sensitization. Until these headaches are better studied and the pathophysiology gets better elucidated, we suggest that careful examination of the surgical scar and its surroundings be conducted in all patients with history of neurosurgery and complaints of new-onset or changing-pattern headaches.

\section{ACKNOWLEDGEMENTS}

The authors thank Dr. Marcelo E. Bigal for critically reviewing the manuscript.

\section{References}

1. Headache Classification Subcommittee of the International Headache Society. The International Classification of Headache Disorders: 2nd edition. Cephalalgia 2004;24(Suppl 1):S9-S160.

2. Pedrosa CA, Ahern DK, McKenna MJ, Ojemann RG, Acquadro MA Determinants and impact of headache after acoustic neuroma surgery. Am J Otol 1994;15:793-797.

3. Schaller B, Baumann A. Headache after removal of vestibular schwannoma via the retrosigmoid approach: a long-term follow-upstudy. Otolaryngol Head Neck Surg 2003;128:387-395.

4. Rocha-Filho PA, Gherpelli JL, de Siqueira JT, Rabello GD. Postcraniotomy headache: characteristics, behaviour and effect on quality of life in patients operated for treatment of supratentorial intracranial aneurysms. Cephalalgia 2008;28:41-48.
5. Mosek AC, Dodick DW, Ebersold MJ, Swanson JW. Headache after resection of acoustic neuroma. Headache 1999;39:89-94.

6. Kaur A, Selwa L, Fromes G, Ross DA. Persistent headache after supratentorial craniotomy. Neurosurgery 2000;47:633-636.

7. Rimaaja T, Haanpaää M, Blomstedt G, Färkkilä M. Headaches after acoustic neuroma surgery. Cephalalgia 2007;27:1128-1135.

8. De Benedittis G, Lorenzetti A, Migliore M, Spagnoli D, Tiberio F, Villani RM. Postoperative pain in neurosurgery: a pilot study in brain surgery. Neurosurgery 1996;38:466-469.

9. Jackson CG, McGrew BM, ForestJA, et al. Comparison of postoperative headache after retrosigmoid approach: vestibular nerve section versus vestibular schwannoma resection. Am J Otol 2000;21: 412-416. 
10. Harner SG, Beatty CW, Ebersold MJ. Impact of cranioplasty on headache after acoustic neuroma removal. Neurosurgery 1995;36:1097-1099

11. de Gray LC, Matta BF. Acute and chronic pain following craniotomy: a review. Anaesthesia 2005;60:693-704.

12. England JD, Happel LT, Kline DG, et al. Sodium channel accumulation in humans with painful neuromas. Neurology 1996;47:272-276.

13. Vernadakis AJ, Koch H, Mackinnon SE. Management of neuromas. Clin Plast Surg 2003;30:247-268.

14. Bendtsen L. Central sensitization in tension-type headache-possible pathophysiological mechanisms. Cephalalgia 2000;20:486-508.

15. Dodick D, Silberstein S. Central sensitization theory of migraine: clinical implications. Headache 2006;46(Suppl 4):S182-S191.

16. Aurora SK, Wilkinson F. The brain is hyperexcitable in migraine. Cephalalgia 2007;27:1442-1453.
17. Kelman L. The triggers or precipitants of the acute migraine attack. Cephalalgia 2007;27:394-402.

18. Anderson DJ, Fallat LM. Complex regional pain syndrome of the lower extremity: a retrospective study of 33 patients. J Foot Ankle Surg 1999;38:381-387.

19. Cramer G, Young BM, Schwarzentraub P, Oliva CM, Racz G. Preemptive analgesia in elective surgery in patients with complex regional pain syndrome: a case report. J Foot Ankle Surg 2000;39:387-391.

20. Rocha-Filho PA, Gherpelli JL, de Siqueira JT, Rabello GD. Postcraniotomy headache: a proposed revision of IHS diagnostic criteria. Cephalalgia 2010;30:560-566.

21. Nguyen A, Girard F, Boudreault D, et al. Scalp nerve blocks decrease the severity of pain after craniotomy. Anesth Analg 2001;93:1272-1276.

22. Wong L. Intercostal neuromas: a treatable cause of postoperative breast surgery pain. Ann Plast Surg 2001;46:481-484. 